\section{Small first step}

\section{France's technology plans hold modest promise.}

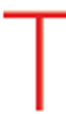

he European Union has identified targets for industrial research and development $(R \& D)$ as critical to its future, but is manifestly failing to meet them. Member states agreed at a 2000 summit in Lisbon to boost total R\&D spending to $3 \%$ of gross domestic product by 2010 - an unrealistic target that the continent will not even begin to move towards unless it sharply boosts private-sector investment.

Last week, French president Jacques Chirac took a step towards addressing that challenge. He announced a $€ 600$-million (US\$760million) plan, to be funded roughly $50-50$ by the French government and by European companies, to support six technology projects. France would eventually increase this to more than $€ 1$ billion annually for dozens of similar projects, he said, in a bid to boost European innovation.

The projects will draw together research programmes on various topics, each championed by a single company, but with the work shared out between a network of others, and also involving laboratories at public research agencies and universities. The largest sum, $€ 250$ million, will fund a Franco-German programme called Quaero, led by Thomson, to develop multimedia search engines. The other projects are smaller, each receiving less than $€ 100$ million.

It is naive to suppose that whole new industries can arise from entrepreneurship alone. Governments can, and must, help create the conditions for innovation, from ensuring a skilled workforce and adequate research infrastructure, to tax breaks and other incentives. Even the United States has long nourished technology development through military contracts and national strategic programmes.

This logic is all the more compelling in Europe, where the reality is that students' and scientists' first thoughts before breakfast are not to go into a garage and launch a company on Nasdaq. The European

Commission's competitiveness ministry will be watching to ensure that the projects do not flout rules on subsidies. Its research ministry, although unhappy at being sidestepped, nonetheless welcomes what it sees as a long-overdue decisive response by member states to the critical lack of private-sector funding of research.

Nevertheless, there are reasons to be cautious about this initiative's prospects for success. France's industrial policies have a decent track record of picking winners its state-sponsored 'grandes programmes technologiques' made the country a world pioneer in high-speed trains and nuclear reactors, and broke US domination of the civilian aerospace industry, creating Airbus and Ariane. These sectors also played to the strengths of France's centralized technocracy in organizing large national and strategic sectors.

But such strengths are less well suited to the dynamics of some of today's key industries
"The new scheme is very much a lapin pulled out of a hat by Chirac in the decrepit dusk of two terms as French president."

- particularly information technology. Although Quaero has wisely ruled out trying to compete head-on with Google, focusing instead on research on next-generation web searching, a top-down approach is unlikely to match the flexibility and speed of bottom-up entrepreneurship.

French domestic politics will also affect the outcome of the new scheme. The 'grandes programmes technologiques' enjoyed national support by successive administrations whatever their political bent. In contrast, the new scheme is very much a lapin pulled out of a hat by Chirac in the decrepit dusk of two terms as French president, where research and innovation have otherwise been largely neglected.

Chirac's initiative at least has the merit of acknowledging the fact that European governments need to address the thorny question of their role in tackling the continent's industrial R\&D deficit.

\title{
Amateur night
}

\section{Ending an inhumane punishment.}

C an the death penalty by lethal injection, as practised in 37 US states, be outlawed as inhumane? The courts are considering this question (see page 8), which can be separated from the more familiar one about the morality of capital punishment.

Their judgements are complicated by the fact that, since the procedure came into use three decades ago, few physicians, nurses or scientists have had anything to do with it. Physicians and nurses are ethically barred from assisting. Yet it is the dominant method in the United States, and has been used to kill more than 800 prisoners there.

Some information has emerged on the workings of the three-drug injection, however. One analysis (L. G. Koniaris et al. Lancet 365, $1412-1414 ; 2005$ ) suggests that $43 \%$ of prisoners might still be conscious, although totally paralysed, when the potassium chloride rips through their veins on the way to stopping their heart.

There are powerful arguments for abandoning the death penalty, regardless of its morality. DNA, for example, has helped prove many death-row inmates innocent, exposing the flaws of an irreversible sanction. And statistical analyses indicate that the death penalty is disproportionately administered to minority populations.

Earlier this year, a California court told state authorities that they must persuade an anaesthetist to oversee an execution, come up with a new protocol for lethal injections - or face a hearing on whether the punishment is inhumane. The last option now looks likely.

If suitably qualified individuals refuse to help prepare a new
"DNA has helped prove many death-row inmates innocent, exposing the flaws of anirreversible sanction." protocol, the state will face the prospect of continuing to use amateurs to kill people with arbitrary and outmoded technology.

Scientists often abjure political activity, and could in this case argue that they are merely providing a basis from which policy-makers can make decisions. But this decision must be taken by the physicians and scientists themselves. All that is required is a refusal to participate. Men and women of science and medicine should stand shoulder to shoulder on this. Don't advise, don't prescribe, don't inject. Let the death penalty die a natural death. 